\title{
La Péri, poème dansé (1911-12): A Problematic Creative-Collaborative Journey
}

\author{
HELEN JULIA MINORS
}

This exploration of the creation of the poème dansé, La Péri (1911-12) for which the score was composed by Paul Dukas (1865-1935) establishes the role played in its development by the première danseuse, Natalia (Natasha) Trouhanova (1885-1956) and other artists. It charts the troubled collaboration on the initial project, which Serge Diaghilev (1872-1929) abandoned in 1911 and follows the process of its presentation the following year under the guidance of Jacques Rouché (1862-1957).

Natalia Trouhanova (1885-1956), ${ }^{1}$ was the only artist apart from the composer to be involved in this production from the outset to its premiere. ${ }^{2}$ How did Trouhanova contribute to the collaborative, creative work between herself as première danseuse and the composer Paul Dukas (1865-1935)? To what extent did her involvement with the production affect Serge Diaghilev's decision not to stage the planned first performance in 1911? How did the theatre director, Jacques Rouché (1862-1957), resurrect the project and inherit Trouhanova as première danseuse?

By early 1911 Dukas had composed the scenario and music for La Péri: ${ }^{3}$ the dance, design and stage direction came later, and it appears likely that the scenario was itself 'born' before the music.. The scenario is in the form of a prose poem without rhyme, of varying syllabic line lengths. The music shimmers with divided strings, punctuating chordal brass and sweeping, high register woodwind, harmonically reminiscent of Rimsky-Korsakov and late-nineteenthcentury programmatic Russian compositions. A French flavour resides in the instrumental combinations and textural layering, with harp glissandi, solo violin melodies and woodwind exchanges.

Diaghilev and his protégé Vaslav Nijinsky (1890-1950) were introduced to La Péri by the impresario and owner of the Théâtre du Châtelet, Gabriel Astruc (1864-1938), in March 1911. Diaghilev was 'determined to get Péri on', as he stated in a telegram to Astruc (27 May 1911). ${ }^{5}$ The first performance, under Diaghilev's guidance with a largely Russian collaborative team, was set for the Ballets Russes season in June 1911 with Nijinsky and Trouhanova in the leading roles, and designs by Diaghilev's colleague, Léon Bakst (1866-1924). 
For reasons outlined below, this production was abandoned at short notice after the performance had been advertised in the Paris press. Many telegrams ensued in which Diaghilev held Trouhanova responsible for a number of the communication problems leading up to the proposed première. Within a year, however, Jacques Rouché had resurrected the project, retaining Trouhanova but with otherwise largely French collaborators. La Péri, poème dansé was finally presented on 22 April 1912 at the Théâtre du Châtelet in Paris. ${ }^{6}$ The collaborative cast, uniting Dukas, Trouhanova and Rouché consisted of Alfred Bekefi (in place of Nijinsky) and replacing Bakst was the painter René Piot (1866-1934). There are extant numerous lists, notes and letters by Trouhanova, addressing almost every aspect of this production from its lighting and scenario issues to marketing and financial details.

\section{DUKAS AND THE STAGE}

In an interview shortly after the eventual premiere of La Péri, Dukas discusses 'successes on the dramatic stage', claiming that a composer 'must write what he feels like writing... what he is inspired to set to music. His work must be the result of an internal impulse which he cannot resist. ${ }^{7}$ Dukas was a prolific music critic, writing over 600 critical articles for the Paris press: these critical pieces overshadow his compositional output in terms of quantity and regularity. A substantial portion of his writings refers to stage works: he was particularly interested in how music relates to the other arts, as is evident in theoretical works such as La Musique et la littérature (1892) and La Déception scénique (1896), in which he enquires why audiences are so often disappointed with theatre productions. ${ }^{8}$

These works set out Dukas's understanding of the function of music in an interdisciplinary work. He situates the poetic idea (the essence of the scenario) at the heart of a work's existence: 'where drama and music merge, one needs on first hearing a little knowledge of the poem and the score. ${ }^{99}$ The order of events during the gestation of La Péri, in which the scenario (in the form of a poem) is written, then music is composed, before the other arts exist, corresponds to Dukas's aesthetic, whereby an understanding of the central idea must be grasped in order to interact with it, follow it, divert from it and project it as the main aim in dramatic staged art.

The oft-cited remark that the total is more than the sum of its parts holds much relevance for music theatre of various styles and genres. But importantly here, for a composer who was actively writing criticism of such extra-musical performances and participating in artistic creative-collaborative relationships in his role as composer, the process of collaborative interplay is itself accorded a vital role in the making of the 'work' (the sum of the many parts). His constant attraction to the theatre extends beyond his many critical articles and the work in question.

Dukas's compositional relationship with the stage had a long and varied development, spanning some 38 years (1892-1930), although it resulted in only one complete ballet, La Péri (1911), and one complete opera, Ariane et 
Barbe-Bleue (1907). Other projects were incomplete sketches and notes, abandoned ideas or destroyed manuscripts (of which there were many). La Péri seems not to have been Dukas's first attempt to write his own scenario, as he had previously written a libretto for an opera, Horn et Rimenhild (1892) and a second largely unacknowledged document housed in the Bibliothèque nationale (1919). ${ }^{10}$ Echos of Wagner occur in Dukas's art and in his many critical articles exploring Wagner, including L'influence Wagnérienne (1923):"1 and in writing his own poetry to which to compose representational music, Dukas was consciously uniting the arts and was undoubtedly considering their 'synchronisation' within the autonomous whole. ${ }^{12}$ For Dukas the solution to the successful staging of a work is not to demand the same of each art form or to attempt to give each medium 'an independent value' - because doing so makes it 'more and more difficult to create the necessary synchronisation. ${ }^{13}$

Other incomplete or destroyed works include Dukas's involvement with another opera, in 1895, though this time he functioned as an orchestrator, as he recalled: 'Saint-Saëns chose me to put together the sketches of Guiraud's Frédégonde, for which he wrote acts four and five. ${ }^{14}$ Dukas made a second attempt to write his own libretto for a four-act work based upon a Hindu legend regarding the tree of knowledge, L'Arbre de Science (1899). ${ }^{15}$ Another operatic venture has only one mention - in a letter from Dukas to his friend Robert Brussel-in which he simply states the provisional title, Le Nouveau Monde (?1908-10). ${ }^{16}$

After completing the composition of his first ballet, La Péri (1911), Dukas immediately started work on another, Le Sang de Méduse (1912). Although limited evidence of this work survives in letters, its timing suggests that Dukas's passion for ballet had been ignited. Dukas signed a contract with Durand for Méduse (30 December 1913), which stipulated that it was to be a single-act poème chorégraphique. ${ }^{17}$ The last stage work that Dukas began was a final attempt at ballet, Variations chorégraphiques (1930). It was never completed, as Rouché comments: 'Dukas] was frowning when he met me on the day appointed for the presentation of the manuscript, he confessed: "I have burnt it". ${ }^{18}$

The starting point, for a study on La Péri rests with the primary source material. In the first place is the question of the original music manuscript and any significant changes or discrepancies between Dukas's manuscript and the published score. Dukas destroyed many of his own works leaving few sketches; so even slight changes assume special significance.

In his manuscript scores, Dukas's musical handwriting is exquisitely neat, suggesting that he retained only fair copies of his work. ${ }^{19}$ The minor pencil alterations that exist reveal Dukas's attention to detail, chiefly regarding tempo and performance directions. Dukas adds 'cédez' and then a short way after 'au mouvement' towards the start and end of sections..$^{20}$ His feeling for progression, particularly at structural 'joins' where thematic material and orchestration change, is considered and purposeful. The super-imposition of these pencil markings on an otherwise final ink score reveals Dukas's perception of the work as a whole. The central structural join, at bar 111, includes a change in direction. Where 'Danse' is noted in bold ink and underlined clearly on the 


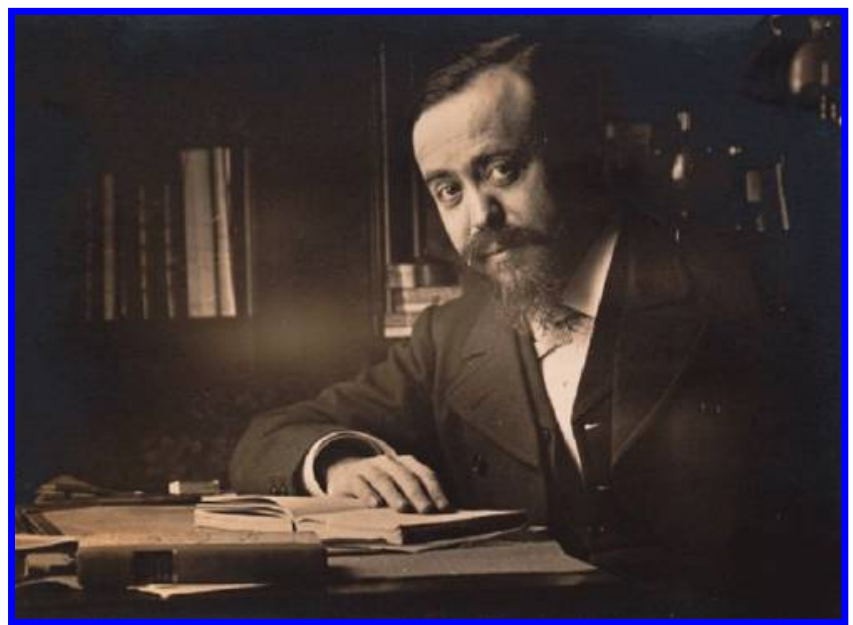

Fig. 1. Paul Dukas. The original image is housed in the Bibliothèque Nationale de France (BNF).

manuscript, Dukas crosses out his original direction in a curving line (above bars 111-13: 'Sans rigueur. Le mouvt s'anime légèrement presque dès le début') and replaces it with a more focused direction: 'Au début: un peu plus animé en avançant.' This is the most extensive change to be found in the manuscript: it is also a point to which Dukas returns in a letter to the conductor Joseph Guy-Ropartz. ${ }^{21}$ This section, with its label 'danse' in a dance-based work, holds meaning and significance for Dukas's interpretation of La Péri. ${ }^{22}$ Bearing in mind the attainment of artistic synchronisation for which Dukas aims, it is perhaps to be expected that the other dance-centred collaborators will grasp the dramatic importance of this music, and adjust their own contributions accordingly.

\section{PLOT OUTLINE AND CONTEXTUALISATION}

The scenario, written as a prose poem without verse divisions, follows Iskender (Alexander the Great) in his search for the flower of immortality. He travels a great distance, in a hot, sun-baked environment. Iskender finds his goal, the supernatural flower, in the hands of a sleeping Péri (female genie); he steals it, hoping for perpetual life. Immediately, the Péri awakes and screams out in alarm. Overwhelmed by her urge to regain her flower, the Péri proceeds to seduce Iskender. Eventually, Iskender is induced to return the flower that had held the promise of immortality for him. As he relinquishes it, the Péri disappears, taking the flower into the heavens: at this point Iskender becomes aware of his own approaching death. ${ }^{23}$

The characterisation of a Péri occurred in at least two other French theatre productions prior to Dukas's creation: firstly in La Reine des Péris: Comédie Persane, by Jacques Aubert (1689-1753). This fully-sung work, based upon a text by Fuselier $^{24}$ and performed at the Académie Royale de Musique (10 April 1725), has 
been hailed as one of the first French comic operas. ${ }^{25}$ Another La Péri (1843) was a ballet by the German composer and stage manager Friedrich Burgmüller (1806-74), with choreography by Jean Coralli (1779-1854) and a libretto by Théophile Gautier (1811-72). ${ }^{26}$ It was first performed at the Académie Royale de Musique, on 22 February 1843, with Carlotta Grisi (1819-99) as the Péri. ${ }^{27}$ As in Aubert's comic opera, Burgmüller's ballet includes a cast of characters that is larger and different from that of Dukas's La Péri. ${ }^{28}$ The similarity seems to lie only with the name of the principal character of these theatrical works, the Péri.

The poem is presented at the front of both the piano reduction and orchestral scores of La Péri, ensuring that at least the performing artists are aware of the plot. ${ }^{29}$ The scenario contains many themes, which include mythology, history and religion. Iskender is the mythological presentation of the idealised conqueror, Alexander the Great. Other ideas are derived from the pre-Islamic religion Zoroastrianism, including the deity 'Ormuzd', who symbolises the principle of goodness, while 'Ahriman' represents evil.

It is uncertain how Dukas knew of Zoroastrianism, but he is likely to have been aware of Rameau's opera, Zoroaster (1749)-which is also concerned with the two opposing powers within this religion-as he had been editing Rameau's complete oeuvre under the guidance of Camille Saint-Saëns. ${ }^{30}$ Dukas's library, moreover, reveals that he had knowledge of Persian poetry and folklore. According to his friend Robert Brussel, Dukas's books 'reflected entirely his personality and tastes... works on music occupy a very small place'; poetry and philosophical texts in 'all languages ${ }^{31}$ predominated. Brussel remarked that his friend's library included the legends of many countries including 'Japan, China' and significantly, 'Persia [with] their refined poetry. ${ }^{32}$

The scenario of $L a$ Péri contains one theme which is of particular relevance to what follows: duality. There are many layers within this work, from the overt character dimension (two characters, female and male, which each projects a specific role within the good-evil axis) to the 'familiar' as against the 'exotic'. Such duality extends beyond the scenario into the dance, design and music.

Exotic tendencies are certainly evident in the scenario of La Péri. The literary cultural historian, Edward Said's study, Orientalism, explores Western perceptions of the East and the powerful influence which a sense of 'otherness' can exert upon the creative process. He states that: 'the Orient is an idea that has a history and a tradition of thought, imagery, and vocabulary that have given it reality and presence in and for the West. ${ }^{33}$ To be exotic, the idea (influence and inspiration), must come from outside the norm, ${ }^{34}$ in other words, for Dukas this exotic stimulus can be classed as anything outside France, and, indeed, Paris, and beyond himself.

The poem for La Péri mirrors aspects of human nature: the desire for permanence within our temporal existence is revealed through the characterisation of the Péri and Iskender. The quest for stability and permanence (in Iskender's lunge for the flower) bring avarice and a desire for personal preservation to the fore, manifested in the coveting of the flower. The flower, implying art, creation, desire and existence, is a multi-faceted symbol that 
changes depending upon its location within the structure of the work; within the thematic, sonorous clothing of the music; within its presence on stage; and within the focus of the characters' preoccupations.

It is pertinent to ask whether there are any musical imagery or balletic allusions within Dukas's scenario: did the composer deliberately encode the poetic text with musical references? There are some specific instrumental remarks: a lute is mentioned (poem, line $3^{35}$ ). It rests upon the breast of the Péri. If the Péri is taken to be an angelic figure, or an entity that represents good, then from a Western perspective this could be related to an angel's harp. Both are stringed instruments that have traditionally been acceptable for women to play.

Looking beyond music to the danced dimension, there is an unambiguous statement that the Péri dances (poem, line 16). The poem is essentially in three parts: the opening (lines 1-15) which charts Iskender's search and then theft of the flower; the middle section comprising only line 16 ('Mais la PÉRI dansa la danse des PÉRIS' ['But the PÉRI danced the dance of Péris']); and the final section (lines 17-23), in which Iskender returns the flower. The single line of the middle section of the poem determines the direction of the action; it accounts for a large part of the music and is essential to the interpretations of the artistic collaborators.

\section{DUKAS AND THE MUSICAL SCORE}

Dukas's self-critical nature resulted in many works and projects being destroyed. The founder of La Revue musicale, Henry Prunières (1886-1943), recounted immediately after Dukas's death that he had 'liked to repeat that all should be burnt at his death. ${ }^{36}$ The near destruction of La Péri is described by the composer and music critic Pierre Lalo (1866-1943), to whom Dukas turned for an opinion of the work's value; it appears that Dukas had threatened to burn the manuscript:

here is a little thing that I did recently ... call it what you want, pantomime, ballet, scène dansée. I am going to show you. But, if you find that it is too bad, then so much the worse for my lost gamble: I will destroy the manuscript; it is all that it merits... Well! That is not worth anything, is it? ${ }^{37}$

Despite Lalo's positive response Dukas posed much the same question to other friends; according to Lalo, the composer Vincent d'Indy (1851-1931) gave Dukas the same positive response as he had done.

Trouhanova requested Dukas to write a ballet for her (as she also did with Ravel ${ }^{38}$ ). Dukas then dedicated the score to her-providing evidence that their working relationship began before the ballet was staged. The dedication appears on both orchestral and piano reduction scores published by Durand in 1911. ${ }^{39}$ Dukas made a gift of the manuscript to Trouhanova, which she later sold: in a letter (3 September 1937) she writes, 'I have asked 10,000 francs. ${ }^{40}$ As a distinct artistic figure Natasha Trouhanova 'serve[d] the cause of modern 
French music' by mounting new French works and communicating directly with French composers, including Ravel, rather than being controlled solely by her impresario. ${ }^{41}$ Her relationship with Dukas had been close before La Péri was mentioned to Diaghilev; it has been suggested by Diaghilev's biographer, Richard Buckle, among others, that Trouhanova was Dukas's mistress. There are postcards written by both Dukas and Trouhanova to their critic friend Brussel while on holiday in January 1911 which support this assertion, but nothing to suggest a long-term intimate relationship beyond this artistic partnership. ${ }^{42}$

La Péri is Dukas's last large-scale orchestral work: its sonorous texture is in many ways typically French and of the early twentieth century; instrumental layering and blending are important elements in its construction. Strings are frequently divided in each part, including the double basses (which rarely received such treatment at this time). Orchestral dynamics are often muted, although the use of contrast is widespread. Musical sections display changes in dynamics and timbre with piano and fortissimo sections using the same chromatic ascending semiquaver motif. Within La Péri these sonorous shifts (dynamic and instrumental) are usually instigated by harp glissandi: for example, leading to bar 49 both harps ascend chromatically connecting a forte full orchestra (bar 48) and a piano, chamber instrumental statement (bar 49). Rapid flute motifs, upper register violins, horn call interjections and double bass tonic pedals, are sonorities that recur throughout La Péri.

Moreover, Dukas uses two main melodic themes which are representative of the two characters, the Péri and Iskender. Dukas distinguishes the themes clearly in the orchestral texture. The Péri is represented by violins and flutes, usually doubling each other. Significantly, the celesta plays the Péri's theme toward the end of the score-a keyboard instrument such as the celesta used within an orchestral score may be regarded as evidence of the influence from the Russian School; Rimsky-Korsakov noted in his orchestration treatise that 'the celesta is only found in full orchestras' as it is in La Péri. ${ }^{43}$ Iskender's theme, by contrast, is almost always played on low-to-mid-range instruments: horns, trombones and bassoons project this theme in a chordal manner. Instrumentation, register and rhythmic motifs characterise these themes, which are manipulated throughout the work. Variation form is employed within the 'danse' section in a refined manner, with a complex version of the theme occurring prior to its simpler re-statement. An awareness of which character theme is being expressed often comes with the movement from an embellished version to a simplified form of the theme. ${ }^{44}$

\section{THE PHOENIX: ABANDONMENT AND REBIRTH}

La Péri appears to have been composed at the piano and orchestrated later, as Dukas revealed in a letter to Edouard Dujardin (27 March 1911): 'I am in the process of orchestrating the little choreographic scene I told you about [La Pér ], and I am really running short on time for this work, which doubtless would be easy for anyone else, but which is slow for me, perhaps because I am difficult and 
overly meticulous. ${ }^{95}$ In the same month, Diaghilev and Nijinsky first heard this piano version in a private presentation organised by Gabriel Astruc to coincide with their visit to Paris. ${ }^{46}$ Diaghilev had immediately seen potential in the work: the first planned performance of La Péri was to be staged by the Ballets Russes that season, in June 1911. This theatrical venture, however, was fraught with problems.

Dukas's aims to synchronise art, to produce a considered correspondence between the arts to express the poem, and to produce an autonomous drama, referring to 'the necessary synchronisation" ${ }^{97}$ between the arts, are reflected in the ideals of Diaghilev. A successful partnership between them seemed to be an aesthetic certainty; though Dukas was rather conservative in approach, in contrast to Diaghilev's controversial and revolutionary repertoire, their aims were much the same. Buckle defines Diaghilev's principal achievement: '[he] had invented a new art form, the ballet as Gesamtkunstwerk... in which all the elements, story (if any), music, décor and choreography, were commissioned by himself to form a complete whole. ${ }^{48}$ Considering Dukas's positive critical engagement with Wagner's aesthetic, and his participation in a staged work beyond the musical score, the ideals of this 'new art form' bear some affinity with Dukas's creative process; Trouhanova, however, is the leading force in commissioning the work, and guiding the creative process and interweaving artistic elements.

Trouhanova's involvement within the production affected the impresario's working process during 1911 to such an extent that Diaghilev did not stage the first performance as planned despite the great effort he had expended on it. Telegrams and letters between Astruc and Diaghilev highlight numerous problems with the production of La Péri, from signing contracts and arranging meetings, to impossible rehearsal schedules. Nijinsky was to be the leading male dancer, appearing with Trouhanova; however, Nijinsky would only agree to this if Dukas conducted. ${ }^{49}$ The ballet was to be choreographed by Michel Fokine (also on the agreement that Dukas conducted) ${ }^{50}$ with set and costume designs by Bakst. Diaghilev wanted to retain performance rights to enable him to present La Péri anywhere in the world. Regardless of Diaghilev's standing, Trouhanova stood her ground, demanding for herself at least four performances. In the end she did not sign a contract. Diaghilev (in a series of telegrams) laid much of the blame for this failure on the danseuse. Equally, Trouhanova complained about Diaghilev and Bakst, giving her 'frank opinion of Diaghilev', and claiming that La Péri was the 'best work' and that Diaghilev had 'cost' Dukas in some way (whether financially or personally, is unclear). ${ }^{51}$ Buckle gives a negative view of Trouhanova, describing her as: 'a dancer-a plump and amateurish one', expressing surprise that 'Dukas wanted her to dance his music'! $!^{52}$ Dukas is presented as supporting Trouhanova. Fokine had grave concerns over Trouhanova's ability for this leading role, as Diaghilev related in his telegrams to Astruc: 'Fokine declared yesterday that to put on Péri with Trouhanova would be the most idiotic thing he had ever let himself in for and something for which he could never forgive himself. ${ }^{53}$ 
Bakst had designed the décor and costumes by May that year, Muelle, the theatrical dressmakers, had been sent these designs and produced the costumes; Trouhanova had then even had her photograph taken wearing the costume. ${ }^{54}$ This photograph was used for the cover of Comodia illustré in June $1911^{55}$ and the design for Iskender had been printed on the cover of the Ballets Russes programme. ${ }^{56}$ The première at the Théâtre du Châtelet was advertised in a preamble by Brussel for Tuesday 6, Thursday 8, Friday 9 and Saturday 10 June $1911 .{ }^{57}$ The friction generated over the costume designs, production rights and publicity were not the extent of the problems. Fokine had 'declared that he would need at least twelve rehearsals' for La Péri. ${ }^{58}$ Diaghilev, realising the potential problems in balancing Fokine's need for rehearsal time and Astruc's demands for the programme schedule, looked to Bakst and Trouhanova to locate blame and secure his own reputation. Blame directed at Bakst seems unreasonable as it is clear that he completed his work on the production.

Diaghilev's view of Trouhanova merits examination. The telegram (22 May 1911) he sent to Astruc (with a copy to Bakst) outlining the difficult situation, illustrates certain communication problems and is suggestive of two domineering, yet enthusiastic, artistic personalities:

We have a fortnight till the Paris opening... I have still not received Trouhanova's contract signed. Indeed you tell me there are things you cannot agree on with her... Obviously we can't plan a work without the co-operation of its chief interpreter [Trouhanova] ... my speciality is to make painters, musicians, poets and dancers work together.

Of all my collaborators the most indispensable has always been Léon Bakst... [yet for] 'Péri' we have had nothing but vague suggestions, possible treatments - nothing more, not even a pencil sketch... As far as Péri is concerned the situation has become absolutely ridiculous, for we are in total ignorance of whether the action takes place in a palace, on a mountain-top or in the clouds-and this is two weeks before the first night... Now I am in a most embarrassing position with regard to Dukas ... ${ }^{59}$

Diaghilev reveals the essence of his art in his remarks to Astruc: he brings the arts and artists together in a creative combination - therefore an inability to meet this aim is a failure on his part as well as a potential public disaster. Diaghilev exaggerates many of the facts - the setting of the work is given in the scenario that prefaces the score, and Diaghilev specifies he has received the piano reduction. Furthermore, Bakst's work had gone beyond Diaghilev's claims of only 'vague' ideas, as Bakst confirms in his telegram of 24 May (1911): 'Protest vehemently against responsibilities you try to place on my shoulders... Péri dispatched last month ... Costumes sent to Muelle ... Péri used cover programme Brunhoff. ${ }^{96}$ At some stage in the artistic synthesis someone had stopped signalling their intentions; regardless of the circumstances, Diaghilev was disassociating himself from the mess. Despite the fact that Diaghilev was 'determined to get Péri on', ${ }^{61}$ he never staged the work. The fiasco continued right up until the last minute: Dukas writes to Diaghilev a mere five days before they should open: 'Nothing is ready. Nothing is signed. ${ }^{62}$ 
Bakst's designs are striking for their intensity of colour. The legs of the Péri are covered in back leggings with split segments revealing flesh, and a speckled orange effect, framed by a blue spilt skirt, topped with a green corset piece revealing breasts and bare arms. The body is finished off with a delicate headpiece, formed from antenna-like extremities and a set of speckled wings. ${ }^{63}$ The image of Trouhanova wearing this costume reveals numerous beads outlining both the head piece and the corset, with a necklace falling from the headpiece around her neck. Iskender's costume is formed from rich reds adorned with navy semicircular patterns; voluptuous fabric trousers flow over the legs. There is a rather large head-piece of the same colour, with fabric hanging from the back down and around Iskender. His arms are semi-revealed through $3 / 4$ sleeves in a kind of chiffon fabric. ${ }^{64}$

Further evidence of how far this planned 1911 production progressed - and with it perhaps the extension of Trouhanova's influence-can be found in Brussel's preliminary report for this concert: he is extremely subjective, since he was a close friend of Dukas and Trouhanova, even more so as he had been contacted by Trouhanova before the performance. Within Trouhanova's planning lists she reminds herself to 'see Brussel. ${ }^{35}$ It appears that Brussel was effectively brought on-side by a sycophantic Trouhanova to ensure his positive support of the concert. His opinions are, however, shared by some other reviewers. It is unclear in the review which 'principle' he is referring to, but as he had heard of La Péri from his friend Dukas, before Rouché's staging, it is possible that he also knew that Dukas and Rouché shared aesthetic values. Both of them believed that the contributing elements should be simplified and synchronised, with each of them bringing something significant to the interpretation of the piece - with nothing redundant.

In his preamble, Brussel hails an event that would bring together artistic 'majesty' and 'subtlety' created within the 'melancholic hearts' of the artists. ${ }^{66} \mathrm{He}$ writes of how Trouhanova is 'guided by [her] instinct' in creating art combining an understanding of both music and dance. ${ }^{67}$ The central page of Brussel's article is an advertisement for Trouhanova's two concerts, to be performed by the Ballets Russes at the Théâtre du Châtelet. ${ }^{68}$

Collaborative projects tend to have problems, changes and resulting compromises; and La Péri is a good illustration of this creative fact. It is a work which brings together artists at contrasting stages in their careers: Rouché embarks on this challenging project during his formative theatre years; Dukas is already a mature artist; Trouhanova appears in a work dedicated entirely to her as a dancer; and lastly, the designer employed by Rouché, René Piot, is in the early stages of his theatre career.

\section{CONCERTS DE DANSE N. TROUHANOWA (1912)}

Within a year of Diaghilev's abandoning the project, La Péri was re-launched with the same danseuse, Trouhanova, and the same costumier, Muelle, but an otherwise new cast, and it became a largely French, as opposed to Russian, 
enterprise ${ }^{69}$ The collaboration was led by Rouché, the director of the Théatre des Arts, who brought together four French ballets by four French composers, with four French artists (of whom all had links to the Théatre des Arts) to produce a dance concert around the talents of Trouhanova.

The Concerts Lamoureux orchestra, founded by Charles Lamoureux in 1881, performed the French works. ${ }^{70}$ There were four performances (as Trouhanova had wished), the first as stated on 22 April, then on 23, 25 and 27 April 1912. ${ }^{71}$ A grey invitation card to the première, which began at $9.15 \mathrm{pm}$, gracefully noted that 'ladies are only received without hats'. ${ }^{72}$ The programme consisted of d'Indy's Istar (designed by George Desvallières), Florent Schmitt's La Tragédie de Salomé (designed by Maxime Dethomas), and the premières of both Dukas's La Péri and Maurice Ravel's Adélaïde ou le langage des fleurs (designed by Piot and Jacques Drésa [also known as André Saglio] respectively).

Trouhanova achieved what Diaghilev had not: she had brought together contemporary French musicians and artists to promote French theatre. As the dance writer Lynn Garafola remarks, both Trouhanova and her contemporary Ida Rubinstein 'offered themselves to the public as Salomés and exotic creatures of mystery. ${ }^{73}$ This remark is highly relevant considering the other exotic works performed alongside La Péri, including Schmitt's Salomé. ${ }^{74}$ Rouché's organisational and artistic talents made this event a counter to the Russiandominated theatre scene; beyond bringing together four leading French composers, he ensured that they conducted their own music.

In an unnamed review of the Concert de Danse which is included in a scrapbook about Trouhanova, Dossier d'Artist $\mathcal{N}$. Trouhanova, she is accredited with producing 'a synthesis of the arts of our time. ${ }^{.75}$ Brussel's review likewise includes a critical perception in accordance with Dukas's aesthetic aim of achieving synchronisation between the arts (synchronised in terms of generating a considered coexistence where each medium contributes to the simplicity of the work): '[Trouhanova] excels in composing ... syntheses remarkable as much for their clarity and accuracy as for the picturesque turn that she gives them. ${ }^{, 76}$

\section{LA PÉRI (PRODUCTION, 1912): CREATION AND COLLABORATION}

\section{-Natalia Trouhanova}

In tracing the creation of La Péri, significant evidence can be found in Trouhanova's extensive paperwork for the project. She considered the finances of this event in detail, ${ }^{77}$ listing costs for: 'I décor', 'II painters', 'III Corps de ballet', 'IV costumes' and 'V various'. ${ }^{78}$ Moreover, she frequently wrote to all the collaborators, especially to Rouché, to confirm dates, programme order and even to suggest artists. ${ }^{79}$ Her choreographic piano reduction score, annotated during the 1912 rehearsals, is housed at the Bibliothèque-Musée de l'Opéra ${ }^{80}$ Lesure noted that the choreographic text was written 'in Russian or in French' by Trouhanova, implying uncertainty over whether both languages 


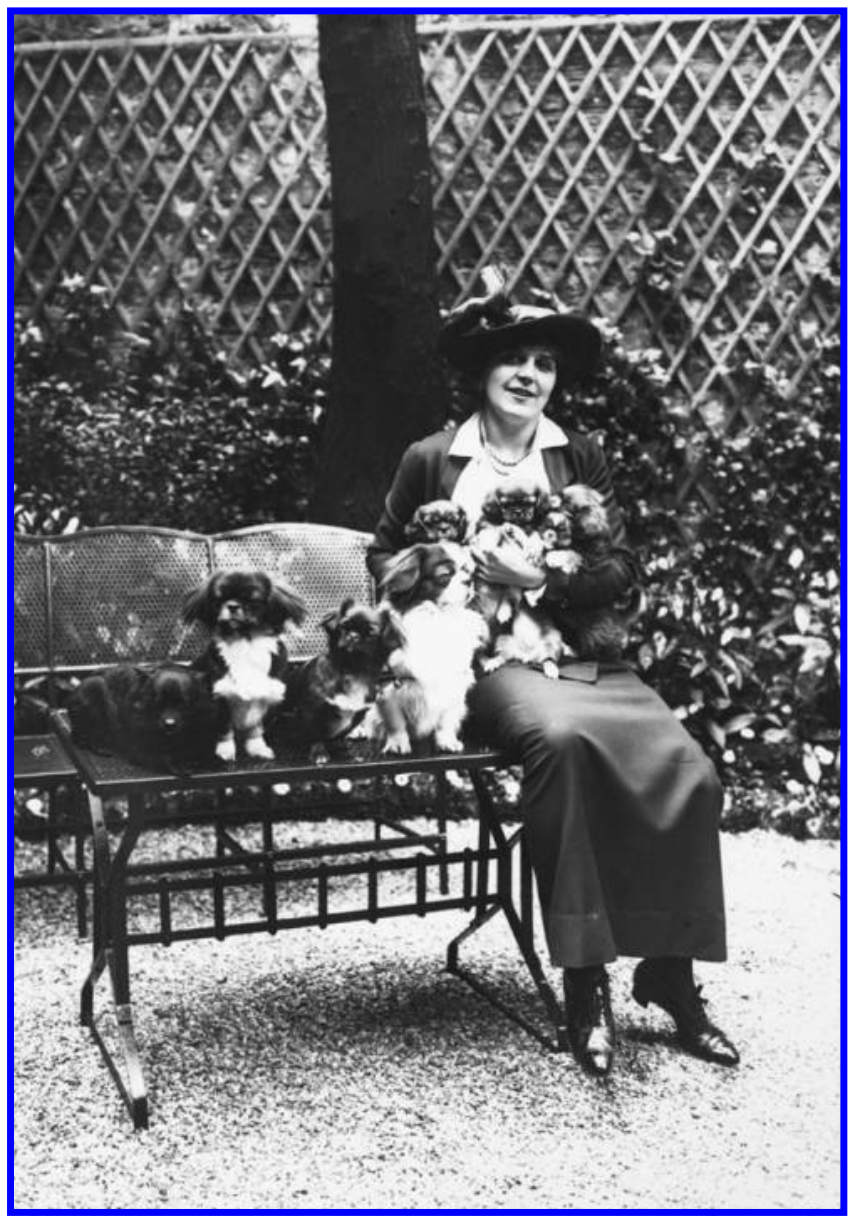

Fig. 2. $M^{\text {elle }}$ Trouhanova, 1913. BNF.

are in Trouhanova's hand.$^{81}$ However, both resemble her writing style in the other Concerts de danse paperwork in the Fonds Rouché and both languages have the same information. ${ }^{82}$ This choreographic score, along with her numerous planning notes and letters explored below, reveals Trouhanova to be a pivotal figure in joining and harmonising the arts and the collaborating artists. Among her many notes Trouhanova seriously examines the scenario ${ }^{83}$ stage planning, costume requirements and programme schedule. ${ }^{84}$ For example, a number of changes occurred in the concert programme which are recorded in her notes: in a letter to Rouché (11 December 1911), Trouhanova lists the works that she is interested in incorporating into her concert, these include two works which did not progress to the final concert: 'the music of Thamar, Istar, Péri, Salomé, Debussy? ${ }^{8}$

Trouhanova made some of the vital decisions in the creative process ${ }^{86}$ agreeing the location of the performances and setting conditions with respect 
to the dates and times of the performances and the overall cost (which was 4,000 Francs).$^{87}$ She also provided a rehearsal schedule and informed Fontanes that:

I will have the same rights as those that are reserved for M. Astruc, in the contract that he has with you, that's to say that I will have a right to the same number of posters of the same dimensions and places and in the same condition. In a word, his publicity (as much outside as inside) in your theatre $\ldots{ }^{88}$

Ivan Clustine (Klyustin (1862-1941), who is accredited with the choreography for the 1912 version of La Péri, already had a working relationship with Trouhanova. He had trained at the Bolshoi ballet, before being installed at the Paris Opéra Ballet as maître de ballet in $1911 .^{89}$ It appears he was the only choreographer considered by Trouhanova for her Concerts, as his name appears in the draft programmes..$^{90}$ During the development of the dance, however, Trouhanova appears to have had a measure of artistic licence, bringing many of her ideas to the work - these are recorded in her own hand on a copy of Dukas's piano reduction score. ${ }^{91}$

Clustine and Trouhanova had worked together previously: he had taught her at the Bolshoi Theatre School; they had partnered each other numerous times; and by 1907 Clustine was acting as Trouhanova's personal choreographer. ${ }^{92}$ The dance historian and critic Lynn Garafola, in a study of Trouhanova's work and style, describes her as a character dancer, performing outside 'classical' genres - the roles that suited her best were those in which she needed to embody a rounded character, as in the four works of the Concerts de danse, which were outside and 'other' to the 'classical' style due to the exotic subject matter. ${ }^{93}$ Henri Gauthier-Villars, in Mercure de France, highlights the detail in her characterisation, while Louis Vuillemin comments on the subtle way in which she unites the arts. ${ }^{94}$ An undisclosed critic, reviewing her recent work in 1908, illustrates as the key to her art the notion that the whole body must inhabit the role: 'the expressive beauty of her face, the harmony of her movements, and the impeccable elegance of her sculptural forms ${ }^{95}$ reveal her as a dancer who has a quality of mime also.

In her annotations to the score Trouhanova precisely linked the music to the poem by the use of numbers. She did the same for stage locations by sketching the occasional small diagram. She also noted her own movement patterns, distinguishing between different types of movement. At the moment before the 'danse' she notes that the Péri offers flowers to Iskender, noting that she is to 'gesture' but not to dance. ${ }^{96}$ She identifies Iskender's role as that of 'gesture', projecting the Péri as the sole dancer.

\section{-René Piot}

Piot's décor and costume designs supported the music, dance and scenario in the 1912 version of $\mathrm{La}$ Péri. ${ }^{97}$ As with the other artists in the collaboration, Piot was actively involved in the collaborative development of the ballet. In a letter 
to Rouché (4 April 1912) ${ }^{98}$ the other ballets, which were performed with La Péri, are referred to in passing, but the focus is Piot's work.

Piot further delineates the characters in a way that is consistent with that of the other collaborators: unlike the Péri, who on the cover of the programme is seated, Iskender is drawn standing with the flower at face height - he has stolen the flower, but does not worship it as does the Péri; to him it is a misunderstood prize. The turban, as Piot described earlier, is topped with two feathers. The Péri seems to be representing the peacock tail of beauty and elegance, whereas the hunter destroys and wears his prize.

Piot was a French painter who turned to theatre design in 1911 at the request of Rouché, producing the décor for Le Chagrin dans le Palais de Han. ${ }^{99}$ Piot later blamed Rouché for bringing him into the artistic realm of the theatre: 'It is true, the theatre is my vice ... it is you who has infected this virus in me. ${ }^{, 100}$

Contrary to Bakst's 'loud' colours and overt exoticism in 1911, Piot's work is subtle, deliberate and illustrates many symbolic associations with both the scenario and Dukas's music. The most striking aspect of Piot's décor for La Péri is his limited use of colour: gold (sky and floor), blue (trees) and pink (stones and mountain). Piot's theatre designs often limit colour; one prominent example is his design for Schmitt's La Tragédie de Salomé of 1919. ${ }^{101}$ For La Péri the limited colour evokes the exotic element in the scenario: orange/gold heat, sandy desertlike Persian landscapes and dry hot cloudless skies. The coldness of the blue only serves to further the richness of the orange. A duality exists within La Péri, as outlined above: a fundamental correspondence is formed between the two prominent colours of the set and the two main characters which act out their role within Piot's setting.

The Péri's costume is in two parts, and was reproduced in the programme alongside the scenario. The front of the costume is illustrated on the front page of the 1912 programme. ${ }^{102}$ Such visual plainness corresponds with the aural rhythmic steadiness. ${ }^{103}$ There is a degree of similarity between the visual and aural dimensions - what the inter-arts theorist, Daniel Albright, might refer to as media-'consonance'104 between the design and the musical main theme for the Péri. Her theme is in 6/8 time, emphasising the triplet nature of the line, consisting of a downward sequence in two parts, with a circular conjunct melody and regular rhythm, each fragment of motif ending with the same rhythmic pattern (presented for the first time at bars 18-21, Example 1).

Example 1: La Péri, the Péri's Theme, bars 18-19 (cor anglais). La Péri, poème dansé en un tableau, partition d'orchestre (Paris: Durand, S.A., Editions Musicales, 1911), bars 18-19 (cor anglais, in F)

Cor A.

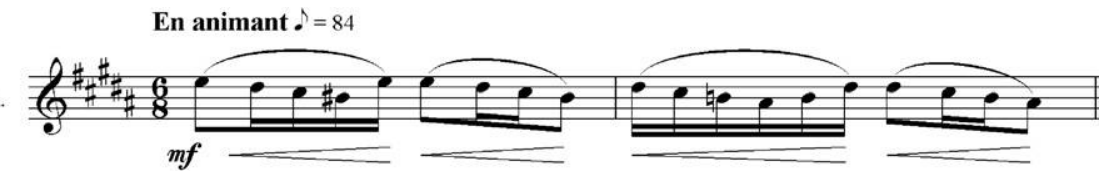


A simple belt frames the Péri's waist, focusing attention on the fact that her lower frame is entirely covered in fabric compared to her upper body which is markedly exposed. It is both innocently presented and erotically suggestive. Yet more correspondences can be made by considering duality and difference: step-wise, rhythmically steady phrases could allude to purity (in that there is limited elaboration of the theme allowing for its essence to be projected), while whole-tone and pentatonic inflections could denote exotic moments because they are both beyond the neutral 'given'-the silent sleeping Péri (at the start) and foundation of tonal harmony. The headpiece is conspicuous because of its elaborate design. Flowing patterned fabric frames the Péri's body, falling from the central headpiece, constructed from petal shaped emblems. Such a continuous curving line is also present in the Péri's musical theme. (Favre, Helbé, Boyd and I identify character specific themes in $\mathrm{La}$ Péri ${ }^{105}$ ) Dukas uses two distinct themes to represent the two characters of the Péri and Iskender. Her theme is conjunct and through each subsequent derivative retains its curving contours.

In contrast, the back of the Péri's costume reveals a highly decorated fabric with meandering flowers (Figure 3). From this perspective it is clear that her headpiece is constructed from large petals at its base, with small petals at its peak, in the form of a large floral bud. Her front is plain, but her back is embellished, suggesting her dual nature; on the one hand calm and sleeping, on the other hand furious and frightened, resorting to sensuous seduction. Her change of attitude is all in the aim of regaining her flower, that goodness, perhaps a symbol of her sexuality. ${ }^{106}$ Such decorative simplicity opposing complexity bears direct affinity with Dukas's musical structure (in that Dukas decorates the main themes, only later simplifying them to reveal a specific character association). Moreover, her theme is often accompanied by an ascending scalic motive which, in a similar fashion to the headpiece and floral design, is more embellished than the theme; it sounds usually below the theme with a faster rhythmic pattern, moving either in a conjunct manner (moving by semi-tone in a chromatic formation, as at bars 18-21, on the first hearing of the theme) or in broken chords (as at bars 32-48). The lines delicately articulated, through slurred melodic fragments played piano.

Her costume has a top layer in the form of a 'long coat', ${ }^{107}$ which is also highly decorated, though not as dense as the reverse of the costume. The sleeves are wide, with a long round train flowing behind. The curving neckline separates the head-piece petals from the torso fabric, and so further contrasts the upper and lower body. ${ }^{108}$ The back of this robe incorporates numerous semi-circular motifs with a dot at the centre, which is reminiscent of peacock feathers. The circular nature of the design bears affinity with the circular, repetitive, variation structure (imposed on a thematic complex-simple movement) that Dukas employs in the music. Such two-part motion exists in the orchestral material, reverting from transparent textures to dense sonorous layering. By moving between the embellished, varied version to the statement, the music reveals specific character themes and sonorities that might be compared to the Péri's true nature being symbolised in her costume (beneath the coat). 


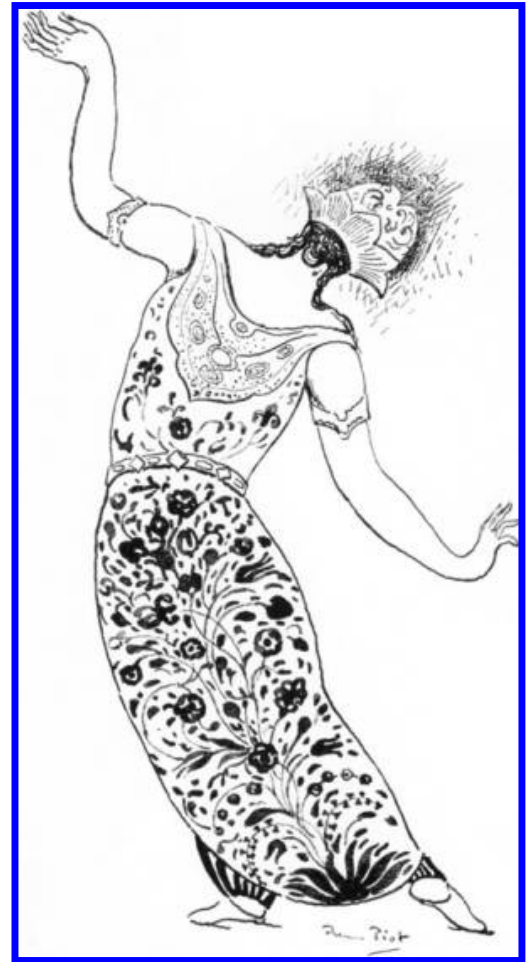

Fig. 3. Programme lllustration: back of the Péri's costume. René Piot, design for La Péri, Programme, Concert de danse N. Trouhanova. Private Collection.

Iskender's costume is described by Piot as a 'long Persian robe made from satin, gold buttons, raised gold paints, on which will be applied a crimson velvet carved with the grand arabesque of embellishments. A belt and sleeves of gold. He is groomed in a grand turban of ivory velvet.' ${ }^{109}$ Iskender's colour palette alludes to opulence. The densely patterned robe consists of vines (Figure 4). Like the Péri, he wears a belt, upon which he carries a dagger. Iskender's costume is darker and denser than that of the Péri. He is the hunter who is armed, wearing a decorated outfit that may be seen to correspond to the rhythmic urgency of his theme and to his quest for the immortal flower. Iskender's theme is constructed from a sustained tonal chord punctuated by mildly dissonant chords in double dotted rhythms, followed by ascending quavers (first presented at bar 16, Example 2): the sharp rhythmic and melodic contours correspond on a basic level to Iskender's more angular costume. It is also worth noting at this stage that the hunting nature of his expedition (from a Western perspective) is mirrored within Dukas's orchestration with frequent use of brass (especially horns) for his fanfare-style theme. This rhythmic interjection and brass associated melody contributes toward his importunate character. 
Example 2: La Péri, Iskender's Theme, bar 16 (trumpets). La Péri, poème dansé en un tableau, partition d'orchestre (Paris: Durand, S.A., Editions Musicales, 1911), bar 16 (trumpets, in $\mathrm{C}$ )
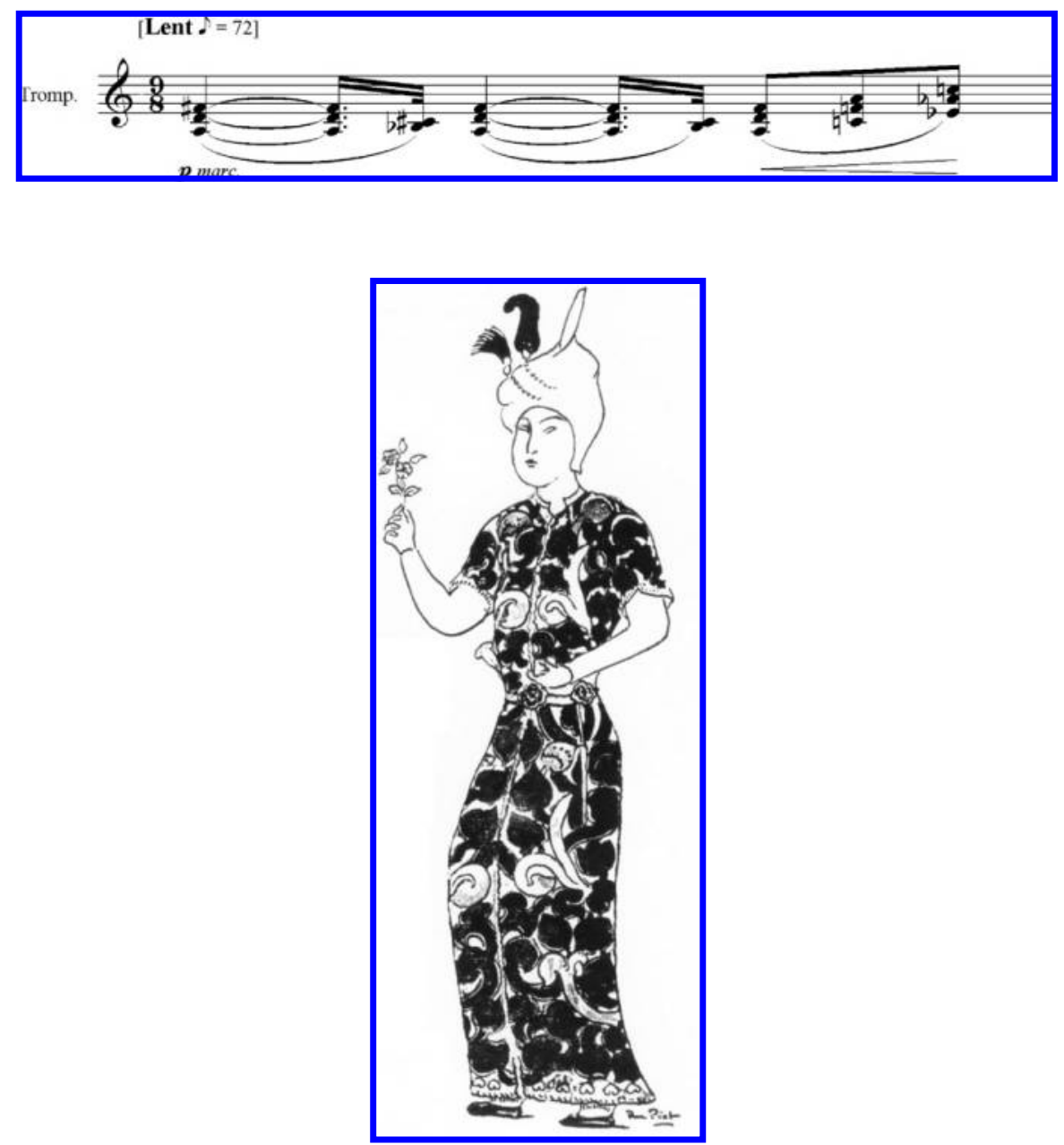

Fig. 4. Programme Illustration: Iskender's costume. René Piot, design for La Péri, Programme, Concert de danse N. Trouhanova. Private Collection.

\section{CONCLUSIONS}

During 1911 disagreements over performance rights, contract details and rehearsal schedule led to Trouhanova choosing not to sign her contract, which in turn left Diaghilev with the only sensible solution: to abandon the project, despite his enthusiasm for the music and the support of Dukas. During 1912 fewer problems appear to have arisen: whether this is due to a changing team or to the fact that Trouhanova kept a clearer eye on the process, is unclear. 
In a sense she project-managed the event by recording as many details as were seen to be important. Rouché, as director, made many financial decisions as well as artistic choices. Trouhanova, as danseuse and commissioner, interpreted the scenario, commenting on lighting, stage location, and characterisation, as well as incorporating the precise text-music relationships into her score. In effect she read the narrative structure of the poem into the music and subsequently her dance.

There is a layering of control and a process of compromise. Each artist contributes their own art form, having made very personal interpretations of what the work requires. Differences emerged between the arts reflecting the duality inherent in the scenario. Trouhanova and Rouché have a similar reading of the structure, although Trouhanova remains faithful to Dukas's scenario, following it to the letter, whereas Rouché adds a trope of Péris (in his 1935 revival) with the aim of creating further variety within an otherwise refined piece.

Trouhanova's character distinctions correlate precisely, in her interpretation, to the musical characteristics. The two themes within La Péri are superimposed within the score at periodic and significant intervals: the last combination occurs at bars 297-8. Trouhanova notes in her score that this is where Iskender returns the Péri's coat, which he had stolen earlier in a desperate attempt to be closer to the Péri during her seduction. As the musical themes meet, the characters interact within the performance space: aural and visual dimensions form a mimetic relationship - the return of the coat signifies the end of Iskender's participation; with both flower and coat returned, the Péri has possession of all she desired. As shown in Example 3, the music retains qualities of both character themes: the double dotted nature of Iskender and the conjunct repetition of the Péri (though her character theme has been manipulated to fit within a 4/4 time signature - a musical compromise).

Example 3: La Péri, bars 297-8 (flute 1 and bassoon 1). La Péri, poème dansé en un tableau, partition d'orchestre (Paris: Durand, S.A., Editions Musicales, 1911), bars 297-8 (flute 1 and bassoon 1).

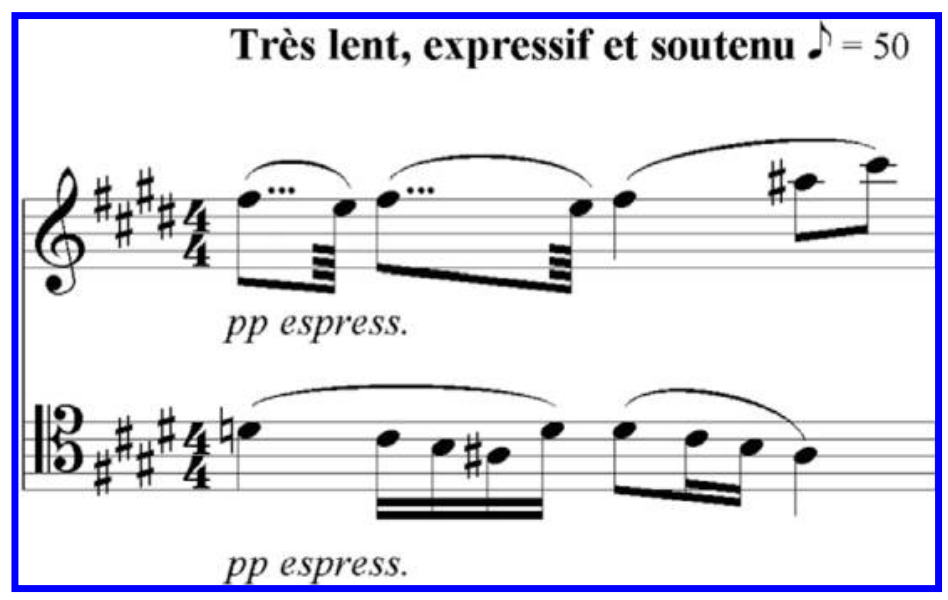


The joining of essentially disparate ideas, mediated by different art forms (by their artists), in order to produce a single work, has much potential to produce confrontation, and by extension, media-'dissonance'. ${ }^{110}$ The director, or impresario, brings these elements together (as Diaghilev implied within his telegram to Astruc and Bakst, cited above). Diaghilev and then Rouché provide and protect artistic coexistence and coherence, while ensuring the flexibility of the performance work. It was Diaghilev's failure to ensure this coexistence which resulted in an abandoned project.

This article has outlined, chronologically, some of the creative discussions, problems and processes within the development of this ballet. What it illustrates is a need to communicate between all artists. What is communicated varies, but personal interpretations and the central aims of the work are major considerations. The evidence demonstrates a link between the artistic decisions made and the artists' aesthetics (specifically of Dukas and Rouché), implying an overall difference in perception stemming from the artists' broader aesthetic approaches. A multilayered, pluralistic, malleable approach has been articulated, situated within the production of an ephemeral work.

\section{ACKNOWLEDGEMENTS}

In memory of my grandad, Alan Jackson.

I am grateful to the help and guidance I received from the staff at the Bibliothèque nationale Paris, most especially the staff at the Bibliothèque-Musée de l'opéra. I would also like to thank Dr. Claire Taylor-Jay for reading an early draft of this essay and for making some welcome suggestions. Likewise I am appreciative of the feedback given by the anonymous reviewers. Finally, I must thank The Society for Dance Research, within whose Established Scholars Conference (March 2008) an early version of this paper was presented.

\section{NOTES}

Abbreviation List

CM - Paul Dukas, Chroniques musicales sur deux siècles 1892-1932 (Paris: Société d'éditions françaises et internationales, 1948).

EPD-Paul Dukas, Les Écrits de Paul Dukas sur la Musique (Paris: Société d'éditions françaises et internationales, 1948).

$\mathrm{BNF}$ - Bibliothèque nationale, Paris.

B-MO - Bibliothèque-musée de l'opéra.

FR - Fonds Rouché.

1. Sources disagree whether $\mathrm{M}^{\text {lle }} \mathrm{N}$. Trouhanova was Natasha or Natalia (Natasha is a diminutive of Natalia). The first version is preferred by Gabriel Astruc; the latter is favoured by Lynn Garafola. Discrepancies exist within the FR, though many of her letters c. 1912 are signed as Natasha. The catalogue of the BNF refers consistently to 'Natalia Vladimirovna Trouhanowa'. Both versions are clearly related. Similarly, surname differences include Trouhanowa and Trouhanova. 
2. Sources of particular relevance in Concerts de danse de Natalia Trouhanowa, Th. du Châtelet 1912, FR, include: Pièce 113, 'Arguments et distribution pour: Salomé, La Péri, Adélä̈de ou le langage des fleurs, Thamar'; Pièce 112, 'Agenda de Rouché pour le mois de mars 1912'; Pièce 100, 'Contrats et Comptes'; Pièce 99, 'Correspondance entre N. Trouhanowa et J. Rouché, documents financiers, facteurs...'; Pièce 98, 'Correspondance relative aux décors et aux costumes'; Pièce 97, 'Correspondance générale'; Pièce 74, 'Théâtre Spectacles de danse de Natalia Trouhanowa 1911-1912.'

3. Michel-Dimitri Calvocoressi notes that Dukas wrote La Péri for Trouhanova in 1910: 'Paul Dukas', The Musical Times, 76/1109 (July 1935), pp. 655-6.

4. Havergal Brian, 'Paul Dukas's La Péri', Musical Opinion (August 1935), pp. 930-1.

5. Reproduced in Richard Buckle, Nijinsky (London: Weidenfeld and Nicolson, 1971), p. 216.

6. The official programme includes no date; the many planning notes in the FR, B-MO, reveal that the date changed numerous times, but the final date is specified by Dukas in a letter inviting his friend, and wife of the famous Spanish composer, Laura Albéniz to his premiere: 'If you had the good sense to come here on the 22 April you would see the performance of La Péri with Istar, Salomé of Fl. Schmitt and a ballet by Ravel: Adélaïde ou le langage des fleurs.' Reproduced in Mercedes Tricas Preckler (ed.), Cartas de Paul Dukas à Laura Albéniz (Barcelona: Bellaterra, 1983), p. 33: 'Si vous aviez le bon sens de venir ici vers le 22 avril vous verriez représenter la Péri avec Istar, la Salomé de Fl. Schmitt et un ballet de Ravel: Adélaïde ou le langage des fleurs.' Copies of the programme are held in Dossier d'Artiste $\mathcal{N}$. Trouhanowa, Dossier d'œuvre La Péri and Pro. A. 768, B-MO.

7. A Paris Correspondent, 'An Interview with Dukas', The Musical Courier (21 August 1912), p. 24.

8. Both these articles are reproduced in CM, 'La Musique et la littérature', pp. 176-9 ; 'La Déception scénique', pp. 186-9. Both were originally published in La Revue hebdomadaire in September 1892 and October 1896 respectively.

9. Paul Dukas, 'Le Théâtre lyrique', in George Favre, Paul Dukas et le Théâtre-Lyrique', Revue d'historie du théatre, 1 (1978), p. 58: 'une œuvre dans laquelle fusionnent le drame et la musique, il faut à première audition en connaître au moins un peu le poème et la partition.'

10. Manuela Schwartz, with G. W. Hopkins, 'Dukas, Paul (Abraham)', in Stanley Sadie (ed.), The New Grove Dictionary of Music and Musicians, 2nd edn, 7 (London: Macmillan, 2001), pp. 670-4. There is a typed document within the Bibliothèque nationale (W51 [96]), from 1919, of a scenario written by Dukas incorporating cultural references. It is unclear what kind of stage work this document may have propagated.

11. Paul Dukas, 'L'influence Wagnérienne', La Revue musicale, 33 (October 1923), pp. 1-9.

12. Dukas, 'La Déception scénique', in CM, pp. 188-9.

13. Ibid., p. 188: 'en prétendant donner au tableau une valeur indépendante, nous rendons de plus en plus difficile la concordance indispensable.'

14. George Favre, Correspondance de Paul Dukas (Paris: Durand et Cie 1971), p. 30: 'En 1895, Saint-Saëns me choisit pour mettre au point les esquisses de la Frédégonde de Guiraud dont il écrivit les $4^{\mathrm{e}}$ et $5^{\mathrm{e}}$ actes. J'orchestrai les trois premiers. L'ouvrage eut huit ou neuf representations.'

15. Letter from Dukas to Humbert, in George Favre, Ibid., pp. 30-1: 'un drame lyrique en quatre actes: L'Arbre de Science.'

16. This letter is referred to in Favre, L'œuvre de Paul Dukas (Paris: Durand et Cie ${ }^{\text {ie }}$ 1969), p. 28.

17. François Lesure, Exposition Paul Dukas: Catalogue (Paris: Bibliothèque Nationale, 1965), p. 13, no. 76. Lesure notes that the idea for this ballet came from Brussel, Dukas's close friend, and that it had been conceived during a trip to Italy. Jacques Helbé also lists this train of events, though wrongly dates it as 1922, in Paul Dukas (Paris: Éditions P.M.P, 1975), p. 32.

18. Georges Favre, L'œuvre de Paul Dukas (Paris: Durand et Cie, 1969), p. 28: 'elle vante l'originalité de la conception et du titre... Froncé en me revoyant, au jour fixé pour la remise du manuscrit, il avouait: je l'ai brûlé.' 
19. Dukas, La Péri, poème dansé, Ms. orch. score with Ms. revisions (1911-12), 118pp, Carlton Lake Collection, Box folder 296.2, Harry Ransom Humanities Research Center, The University of Texas, at Austin, TX. Thanks to the staff of the Research Center for their help. There must have been drafts and incomplete versions of this work as Dukas orchestrated it once he had already composed the thematic material.

20. For example, at bars 23, 27 respectively, and at 313 and 314 of the manuscript, La Péri, Ms. orch. score.

21. Favre, Correspondance, p. 135: letter of 13 January 1920, in which Dukas refers to the tempo indication at the 'danse'.

22. The section starting at bar 111 is read as significant by both dancer, Trouhanova, and director, Rouché: see Helen Julia Minors, 'Paul Dukas' La Péri as Interpreted by Two Balletic Collaborators', Opera Quarterly: Performance, Theory, History, 22/1 (Winter, 2006), pp. 117-35.

23. The poem is printed in both piano reduction and orchestral scores: Paul Dukas, $L a$ Péri, poème dansé en un tableau, partition d'orchestre (Paris: Durand, S.A., Editions Musicales, 1911); La Péri, poème dansé, réduction pour piano par Léon Roques (Paris: A. Durand et fils, 1911). A translation of this poem support by a commentary of its historical, mythological and artistic references can be found in, Helen Julia Minors, 'La Péri, poème dansé (1911, Paul Dukas) in its cultural, historical and interdisciplinary contexts', unpublished Ph.D. Dissertation (Lancaster University, 2007), pp. 62-74; pp. 232-3.

24. J.B. Christophe Ballard, Recueil général des opéras: représentez par l'académie royale de musique, vol. 13 (Paris: De l'Imprimerie de royale de academie royale de musique, au mont Parnasse, 1734), pp. 319-92: US 2081 (3) B-MO. Reprinted as Recueil général des opéras, vols 1-16 (Genève: Slatkine, 1971). Special thanks to the staff at the B-MO for allowing me to explore some of these earlier publications extending beyond this current research. The scenario for this ballet is much longer than that by Dukas and includes many more characters.

25. Elizabeth Keitel and M. Signorile, 'Jacques Aubert', in Stanley Sadie (ed.), The New Grove Dictionary of Music and Musicians, $2^{\text {nd }}$ edn, 2 (London: Macmillan, 2001), p. 157.

26. Théophile Gautier, Histoire de l'art dramatique en France depuis vingt-cinq ans, vol. 3 (Leipzig: Editions Hetzel Alphonse Durr, 1859), pp. 76-83.

27. Jon Chapman, 'La Péri', in Martha Bremser (ed.), International Dictionary of Ballet, vol. 2 (London: St. James Press, 1993), p. 1102.

28. Simon-Pierre Perret and Maria-Laure Ragot refer to two other works including a Péri by name and production date, but they do not give any details of the productions stating genre or style, nor do they reference the information: John Clarck (1825) and (Jules Philippot) 1871, in Paul Dukas (Paris: Fayard, 2007), p. 277.

29. See endnote 23 .

30. Under the direction of Camille Saint-Saëns (1835-1921), Rameau's complete æuvre was edited and then published by Durand. Dukas's Rameau contributions consisted of: Les Indes galantes, volume 7 of Rameau's complete æuvre (1906); in volume 11 (1901), La princesse de Navarre, Les Fêtes de Ramire, Nélée et Myrthis and Zéphire. Graham Sadler describes Dukas's editing as 'seriously flawed', in 'Vincent d'Indy and the Rameau Oeuvres complètes: A Case of Forgery?', Early Music, 21/3 (August 1993), p. 415.

31. Brussel, 'Sur le chemin du souvenir', La Revue musicale, 166 (May 1936), p. 27: 'La bibliothèque de Paul Dukas reflétait entièrement sa personnalité et ses goûts... les travaux sur la musique occupaient une très petite place ... toutes langues.'

32. Ibid.: 'le Japon, la Chine, la Perse et leur poésie raffinée.'

33. Edward W. Said, Orientalism: Western Conceptions of the Orient (London: Penguin Books, 1978, 1995, 2003), p. 5.

34. Robert Orledge, 'Evocations of Exoticism', in Deborah Mawer (ed.), Cambridge Companion to Ravel (Cambridge: Cambridge University Press, 2000), p. 43.

35. Scenario, Line 3, 'Et là, sur les degrés qui conduisent aux parvis d'Ormuzd, une PÉRI était étendue, dormant dans sa robe de pierreries. Une étoile scintillait au-dessus de sa tête, son luth reposait sur son sein et dans sa main la Fleur brillait.' ['And there, on the steps which lead to the temple Ormuzd, a PÉRI was stretched out, sleeping in her dress 
covered with precious stones. A star shone above her head, her lute rested upon her breast and in her hand the Flower shone.']

36. Henry Prunières, 'Adieu à Paul Dukas', La Revue musicale, 157 (June 1935), p. 3: 'Dukas aimait à répéter que tout serait brûlé à sa mort.'

37. Pierre Lalo, De Rameau à Ravel: portraits et souvenirs (Paris: Éditions Albin Michel, 1947), p. 185: 'voici une petite chose que j'ai faite dernièrement... appelez-la comme vous voudrez, pantomime, ballet, scène dansée. Je vais vous la montrer. Mais, si vous trouvez que c'est trop mauvais, tant pis pour ma gageure perdue: je détruis le manuscrit; c'est d'ailleurs tout ce qu'il mérite... Eh bien! ça ne vaut rien, n'est-ce pas?'

38. Trouhanova commissioned Ravel to write a ballet for her: Concert de danse. However, this commission placed Ravel in a precarious situation. He was simultaneously working with Trouhanova and Diaghilev on two different projects: he was left situated between Trouhanova (Adélä̈de) and Diaghilev (Daphnis), who had 'dropped' La Péri in 1911. As Gerald Larner notes, 'Ravel could scarcely have failed to be aware that he was being drawn into an awkward political situation.' Gerald Larner, Maurice Ravel (London: Phaidon Press Limited, 1996), p. 127.

39. Dukas, La Péri, poème dansé en un tableau, partition; La Péri, poème dansé, réduction pour piano par Léon Roques.

40. Pièce 99, doc. 25, FR, B-MO.

41. Lynn Garafola, Legacies of Twentieth-Century Dance (Middletown, CT: Wesleyan University Press, 2005), p. 59.

42. Postcard from Dukas and Trouhanova to Brussel (26 January 1911), N.L.a 26 (082), Département de la musique, BNF.

43. Nikolai Rimsky-Korsakov, Principles of Orchestration, ed. Maximillian Steinburg, trans. Edward Agate (New York: Dover Publications, 1964), p. 32. The celesta is a French instrument, invented by Auguste Mustel in 1886; it was quickly employed in Russia, for example Tchaikovsky's Nutcracker (1892) allocates a main theme to the instrument.

44. Though this essay does not offer an analysis of the music, musical details are necessary as I chart the artists' interactions and interpretations during the creative process.

45. Letter from Dukas to Dujardin (27 March 1911), in Moore, 'The Significance in the Relationship of Paul Dukas and Edouard Dujardin', p. 328: 'Je suis en train d'instrumenter le petit tableau chorégraphique dont je vous ai parlé et je suis très à court de temps pour ce travail facile sans doute pour un autre mais qui pour moi est lent, peutêtre parce que je suis difficile et vétilleux.' Moore does not provide the archival source of this letter.

46. Richard Buckle, Diaghilev (London: Weidenfeld and Nicolson, 1979), p. 182. Gabriel Astruc's papers are housed in The New York Public Library, collection ZBD-161, Dance Collection, see Paper of Gabriel Astruc 1906-1914. These papers include two extensive letters regarding $\mathrm{La}$ Péri. For ease of access to a fuller version of these letters I cite herein Buckle's biographies of Diaghilev and Nijinsky as they usefully reproduce large portions of these letters.

47. Dukas, 'La Déception scénique', in $C M$, p. 188: 'nous rendons de plus en plus difficile la concordance indispensable'

48. Buckle, Diaghilev, p. 182

49. Telegrams from Diaghilev to Astruc (3 April 1911), New York Public Library, (S) *MGZMC-Res. 1, in Buckle, Diaghilev, p. 199.

50. Telegram from Diaghilev to Astruc (23 March 1911), ibid.

51. Pièce 99, doc. 17 (January 1912), FR, B-MO.

52. Buckle, Nijinsky, p. 199.

53. Diaghilev writing to Astruc, on 27 May 1911, in Buckle, Nijinsky, p. 216.

54. Bakst confirms that his costume designs are complete and sent to Muelle in a telegram to Diaghilev (24 May 1911). In Buckle, Nijinsky, p. 215.

55. Photograph of Trouhanova wearing Bakst's costume, Cover to Comædia illustré (15 June 1911)

56. Bakst's costume designs for Iskender and Péri are reproduced in many text books and also delivered as posters through current art websites. Trouhanova's photograph is 
reproduced in Alexander Schouvaloff, Léon Bakst: The Theatre Art (London: Sotheby's Publications, 1991), p. 118.

57. Robert Brussel, 'Préambule: Pour deux Concerts de danse', Le Courrier musical, 1 (1 May 1911): central plate advertisement.

58. Buckle, Nijinsky, p. 216.

59. Letter from Diaghilev in Rome to Astruc in Paris (22 May 1911). Reproduced in Buckle, Nijinsky, pp. 213-15. The first reference to La Péri was in a telegram to Astruc from Diaghilev (14 February 1911).

60. Telegram from Bakst to Diaghilev (24 May 1911), ibid., p. 215.

61. Telegram from Diaghilev to Astruc (27 May 1911), ibid., p. 216.

62. Letter from Dukas to Diaghilev (7 June 1911), in Autographes musicaux: manuscrits et lettres de compositeurs (Vente aux enchères publiques le 20 juin 1977) (Paris: Drouot, 1977), p. 108: 'Cinq jours seulement... Rien n'est réglé. Rien n'est signé.'

63. Bakst's design for the Péri is reproduced in Garafola and Baer, The Russian Ballet and Its World, Plate 12. The original is housed at the Theatre Museum, Victoria and Albert Museum, London.

64. Bakst's design for Iskender was printed on the front cover of the Ballets Russes Programme (1911). The design as printed on the programme cover is reproduced Ibid., Plate 11

65. Pièce 99, doc. 9, FR, B-MO: 'voir Brussel.'

66. Robert Brussel, 'Préambule: Pour deux Concerts de danse', Le Courrier musical, 1 (1 May 1911), 310: 'majestueux ... subtibilités [sic: subtilités] ... dans leur cœur mélancolique.'

67. Ibid.: '. ... guidée par un instinct.'

68. Ibid.: central plate advertisement.

69. Robert Brussel, 'De la musique et de la danse: Les Concerts de $\mathrm{M}^{\mathrm{lle}}$ Trouhanowa', $\mathrm{La}$ Revue musicale et SIM, 8/5 (15 May 1912), p. 58.

70. Roger Nichols, The Harlequin Years: Music in Paris 1917-1929 (London: Thames and Hudson, 2002), pp. 43, 54.

71. Pièce 100, doc. 2, FR, B-MO: a costing form for 'Quatre Concerts de Danse', in which Trouhanova clearly outlines these dates.

72. Pièce 97, doc. 36, FR, B-MO: 'Les Dames ne seront reçues que sans chapeau.'

73. Garafola, Legacies of Twentieth-Century Dance, p. 149.

74. Salomé had hit Parisian culture with works celebrating the identity of this character. For further information see, Davinia Caddy, 'Variations on the Dance of the Seven Veils', Cambridge Opera Fournal, 17 (2005), pp. 37-58.

75. Unattributed, 'Mme Trouhanowa-Ignatieff à Lyons', Lyon-Républicain (17 March 1935), in Dossier d'Artist $\mathcal{N}$. Trouhanova, B-MO: 'une synthèse de l'art de notre temps.'

76. Brussel, 'De la musique et de la danse', p. 59: 'Elle excelle à composer des unes et de l'autre des synthèses remarquables aussi bien par leur netteté et leur justesse, que par le tour pittoresque qu'elle leur donne.'

77. Pièce 100 , doc. 2, FR, B-MO.

78. Pièce 100 , doc. 5 , FR, B-MO.

79. Pièce 100, doc. 4, FR, B-MO: Letter from Trouhanova to Rouché (11 February 1912).

80. Rés. A. 734, Dukas, Paul, La Péri, poème dansé, réduction pour piano par Léon Roques (Paris: A. Durand et fils, 1911). Exemplaire de N. Trouhanowa, sur lequel la danseuse a porté en russe ou en français, de nombreuses indications sur la chorégraphie.

81. Lesure, Exposition: Paul Dukas Catalogue, p. 12.

82. I am grateful to Prof. Andrew Jameson (Lancaster University) for his advice on the content of the Russian text.

83. Trouhanova produced a handwritten, crayon copy of the scenario (Pièce 113, doc. 4, FR, B-MO) upon which she added additional comment regarding lighting. Trouhanova underlines specific sentences (which link to her score annotation) and forms associations between the flower and the lighting remarks.

84. Pièce 99, doc. 7, FR, B-MO, lists a possible programme of works.

85. Ibid.: 'la musique de Thamar, Istar, Péri, Salomé, Debussy? .' 
86. Pièce 100, doc. 16, FR, B-MO: Letter from Trouhanova to Fontanes (27 January 1912): 'J'accepte vos conditions pour la location du Théâtre du Châtelet, pour les concerts de danses que je compte y donner au mois d'avril.' [I accept your conditions for the hire of the Théâtre des Châtelet, for the dance concerts that I plan to give there in the month of April.]

87. Ibid.: ' '.. pour le lundi 22 avril en soirée, pour le somme de 4,000 fr.'

88. Ibid.: 'j'aurai les mêmes droits que ceux que s'est réservé Monsieur Astruc, dans le contrat qu'il a avec vous, c'est-à-dire que j'aurai droit au même nombre d'affiches de mêmes dimensions et placées dans les mêmes conditions. En un mot, sa publicité (tant extérieure qu'intérieure) dans votre théâtre....' Signed, 'Natasha TROUHANOWA.'

89. Cyril Beaumont, Ballets Past and Present (London: Hazel Watson \& Viney Ltd, 1946), p. 228.

90. Pièce 97 , doc. 30, FR, B-MO

91. Rés. A. 734, Dukas, Paul, La Péri, poème dansé, réduction pour piano par Léon Roques (Paris: A. Durand et fils, 1911), Exemplaire de N. Trouhanowa, sur lequel la danseuse a porté en russe ou en français, de nombreuses indications sur la chorégraphie.

92. Garafola, Legacies of Twentieth-Century Dance, pp. 150, 151.

93. Ibid., 151.

94. Henry Gauthier-Villars, 'Musiques', Mercure de France (16 May 1912), p. 414, in Garafola, Legacies of Twentieth-Century Dance, p. 155. Louis Vuillemin, Revue d'histoire du théâtre, cited in Dominique Garbon, Jacques Rouché: L'homme qui sauva l'Opéra de Paris (Paris: Somogy Editions d'art, 2007), p. 104.

95. 'Les Deux Pigeons', Fournal de Monaco, 7 (May 1908), ibid.

96. Rés. A. 734, p. 14

97. I am grateful to Susan Bagust for inviting me to present an early version of my work on Piot and La Péri at 'Musical Iconography' RMA Study Day, University of Sheffield (July 2005).

98. This letter reveals that the coat alone cost over 600 francs. Pièce 74 , doc. 9, FR, BMO: Letter from Maurice and Henri Monnot to Rouché (4 April 1912): 'D'accord avec M. Piot, je vous envoie ci-dessous le prix pour le grand manteau rose de $\mathrm{M}^{\mathrm{lle}}$ Trouhanowa... il faut compter $600+$.'

99. The Théâtre des Arts staged Le Chagrin dans le Palais de Han, based on Louis Laloy's translation of the $13^{\text {th }}$-century Chinese play with music by Gabriel Grovlez.

100. Cited in Rodolphe Rapetti, René Piot: fresquiste et décorateur. Dossiers du musée d'Orsay (Paris: Editions de la réunion des musées nationaux, 1991), p. 32: 'C'est vrai, le théâtre est mon vice,... c'est vous qui m'avez inoculé ce virus.'

101. Incidentally a work that was performed alongside La Péri in 1912, though designed by a colleague of Piot, Maxime Dethomas. This design, which is predominantly dark green, is reproduced in René Piot fresquiste et décorateur.

102. Similarities to the other designs for the Péri can be seen in the head piece. The Péri holds her flower aloft in both photograph and design. This programme cover image has been reproduced in other discussions of this work, including a black and white plate in Bénédicte Palaux-Simonnet, Paul Dukas ou le musicien-sorcier (Geneva: Editions Papillon, 2001), p. 88.

103. Suggested further reading: Stephanie Jordan, Moving Music: Dialogues with Music in Twentieth-Century Ballet (London: Dance Books, 2000), 15; and Inger Damsholt, 'Mark Morris, Mickey Mouse, and Choreomusical Polemic', Opera Quarterly: Performance, Theory, History, 22/1 (Winter, 2006), pp. 4-21.

104. Daniel Albright, Untwisting the Serpent: Modernism in Music, Literature, and Other Arts (Chicago: University of Chicago Press, 2000).

105. Favre, L'œuvre de Paul Dukas; Helbé, Paul Dukas. Boyd, Everett Vernon, Jr, 'Paul Dukas and the Impressionist Milieu: Stylistic Assimilation in Three Orchestral Works', unpublished Ph.D. Dissertation (Eastman School of Music, 1980); Minors, 'La Peri, poeme danse (1911, Paul Dukas) in its cultural, historical and interdisciplinary contexts'. 
106. Hughes went as far as to state that La Péri was 'a successful attempt to portray in music the physical sensation of sexual intercourse', in Gervase Hughes, Sidelights on a Century of Music 1825-1924 (London: MacDonald, 1969), p. 105.

107. Pièce 74, doc. 9, FR, B-MO: Letter from Monnot to Rouché (4 April 1912): 'le grand manteau rose de $\mathrm{M}^{\text {lle }}$ Trouhanowa.'

108. Trouhanova and Bekefi are photographed together, on stage, in character; reproduced in Brussel, 'De la musique et la danse', plate 2.

109. Piot, Excelsior (29 March 1922), reproduced in Rapetti, René Piot fresquiste et décorateur, p. 49: '[une] longue robe persane composée d'un satin bouton d'or rehaussé de peintures d'or et sur lequel sera appliqué un velours pourpre sur lequel on découpera les grandes arabesques des ornements. Ceinture d'or et manches d'or. Il est coiffé d'un grand turban en velours ivoire.'

110. Albright, Untwisting the Serpent.

\section{SELECT BIBLIOGRAPHY}

\section{Primary Sources:}

Bibliothèque-musée de l'opéra (B-MO), Bibliothèque Nationale, Paris (BNF)

Dossier d'artiste, Paul Dukas.

Dossier d'artiste, Trouhanowa.

Dossier d'œuvre, La Péri, de Paul Dukas.

Fonds Rouché (FR), Th. des Arts, Arch. R8 (4), Pièce 15, Concerts de danse de Natalia Trouhanowa, Th. du Châtelet, 1912 Pièces 97-100, 112-13 ; Pro. A. 768., Programmes des Concerts danse $\mathcal{N}$. Trouhanowa (1912).

Manuscripts (on reserve): Rés. A. 734, Dukas, Paul, La Péri, poème dansé, réduction pour piano par Léon Roques (Paris: A. Durand et fils, 1911), Cette partition est annotée par Rouché à l'encre noire et à l'encre rouge. Nouvelle version proposée par l'auteur. On a joint la mise en scène (February 1935).

Bibliothèque de la musique $(\mathrm{BNF})$

BN Mus. N.L.a. $26(082,599)$ Carte de Paul Dukas et Natasha Trouhanowa à Robert Brussel (26 January 1911, 3 September 1912).

Harry Ransom Humanities Research Center, The University of Texas, as AustinTX

Paul Dukas, La Péri, poème dansé, Ms. orch. score with Ms. revisions (1911-12), 118pp, Carlton Lake Collection, Box folder 296.2.

The New York Public Library

Dance Collection, Collection ZBD-161, Papers of Gabriel Astruc 1906-1914.

\section{Published Sources:}

A Paris Correspondent, 'An Interview with Dukas', The Musical Courier (21 August 1912), p. 24.

Everett Vernon Boyd, Jr, 'Paul Dukas and the Impressionist Milieu: Stylistic Assimilation in Three Orchestral Works', unpublished Ph.D. Dissertation (Eastman School of Music, 1980). Havergal Brian, 'Paul Dukas's La Péri', Musical Opinion (August 1935), pp. 930-1.

Robert Brussel, 'De la musique et de la danse: Les Concerts de $\mathrm{M}^{\text {lle }}$ Trouhanowa', La Revue musicale et SIM, 8/5 (15 May 1912), pp. 55-60.

—_ 'Préambule: Pour deux Concerts de danse', Le Courrier musical, 1 (May 1911), pp. 310-11.

_. 'Sur le chemin du souvenir', La Revue musicale, 166 (May 1936), pp. 18-51.

Richard Buckle, Diaghilev (London: Weidenfeld and Nicolson, 1979).

- Nijinsky (London: Weidenfeld and Nicolson, 1971).

M. D. Calvocoressi, 'Les Concerts de danses de M ${ }^{\text {lle }}$ Trouhanowa', Comodia illustré (15 May 1912), p. 638 . 
Jean Chantavoine, 'La musique française en 1912', L'Année musicale, 2 (1912), repr. (Geneva: Minkoff reprints, 1972), pp. 227-32.

Paul Dukas, La Péri, poème dansé, réduction pour piano par Léon Roques (Paris: A. Durand et fils, 1911).

, La Péri, poème dansé en un tableau, partition d'orchestre (Paris: Durand, S.A., Editions Musicales, 1911).

_ C Chroniques musicales sur deux siècles 1892-1932 (Paris: Société d'éditions françaises et internationales, 1948).

— Les Écrits de Paul Dukas sur la musique (Paris: Société d'éditions françaises et internationales, 1948).

, 'L'influence Wagnérienne', La Revue musicale, 33 (October 1923), pp. 1-9.

George Favre, 'Paul Dukas et le Théâtre-Lyrique', Revue d'histoire du théâtre, 1 (1978), pp. 55-70. Correspondance de Paul Dukas (Paris: Durand et $\mathrm{C}^{\mathrm{ie}}, 1971$ ).

L'cuvre de Paul Dukas (Paris: Durand et Cie, 1969).

Théophile Gautier, Histoire de l'art dramatique en France depuis vingt-cing ans, vol. 3 (Leipzig: Editions Hetzel Alphonse Durr, 1859), pp. 76-83.

Lynn Garafola and Nancy Van Norman Baer, The Russian Ballet and Its World (New Haven: Yale University Press, 1999).

Lynn Garafola, Legacies of Twentieth-Century Dance (Middletown, CT: Wesleyan University Press, 2005).

Jacques Helbé, Paul Dukas (Paris: Editions P.M.P., 1975).

Pierre Lalo, De Rameau à Ravel: portraits et souvenirs (Paris: Éditions Albin Michel, 1947), p. 185.

François Lesure, Exposition Paul Dukas: Catalogue (Paris: Bibliothèque Nationale, 1965).

Helen Julia Minors, 'La Péri, poème dansé (1911, Paul Dukas) in its cultural, historical and interdisciplinary contexts', unpublished Ph.D. Dissertation (Lancaster University, 2007).

_ - 'Paul Dukas' La Péri as Interpreted by Two Balletic Collaborators', Opera Quarterly: Performance, Theory, History, 22/1 (Winter 2006), 117-135.

Bénédicte Palaux-Simonnet, Paul Dukas ou le musicien-sorcier (Geneva: Editions Papillon, 2001).

Jacques Pillois, 'A propos d'un Concert de danse: $\mathrm{M}^{\text {lle }}$ Trouhanowa dans des oeuvres de Vincent d'Indy, Paul Dukas, M. Ravel et F. Schmitt ', Le Courrier musical (May 1912), 266-8.

Mercedes Tricas Preckler (ed.), Cartas de Paul Dukas à Laura Albéniz (Barcelona: Bellaterra, 1983).

Moore, William Angus II, 'The Significance in the Relationship of Paul Dukas and Edouard Dujardin: A Study of their Correspondence, Essays on Wagner, and Dukas's Opera Ariane et Barbe-Bleue', unpublished Ph.D. Dissertation (The University of Texas, 1986).

Henry Prunières, 'Adieu à Paul Dukas', La Revue musicale, 157 (June 1935), 3.

Rodolphe Rapetti, René Piot: fresquiste et décorateur. Dossiers du musée d’Orsay (Paris: Editions de la réunion des musée nationaux, 1991).

Jacques Rouché, L'art théatral moderne (Paris: Edouard Cornley, 1910).

Manuela Schwartz, with G. W. Hopkins, 'Dukas, Paul (Abraham)', in Sadie, Stanley (ed.), The New Grove Dictionary of Music and Musicians, 2nd edn, 7 (London: Macmillan, 2001), 670-4. 